\title{
Proceeding Determination of genetic relatedness of selected individual trees of Shorea leprosula Miq. and Dipterocarpus cornutus Dyer in forest seed production areas
}

\author{
Wickneswari Ratnam \& Ho Wei Seng ${ }^{1)}$ School of Environmental and Natural Resource Sciences, Faculty of Science and Technology, \\ Universiti Kebangsaan Malaysia, 43600 UKM Bangi, Selangor, Malaysia. \\ ${ }^{2)}$ Present address: Faculty of Resource Science and Technology, Universiti Malaysia Sarawak, 94300 Kota Samarahan, Sarawak, Malaysia.
}

\begin{abstract}
The genetic relatedness of selected mother trees of Shorea leprosula (24 trees) and Dipterocarpus cornutus (10 trees) was investigated using four simple sequence repeats (SSRs) loci in two seed production areas, a 1 ha seed stand of S. leprosula and a 0.9 ha seed stand of D. cornutus in Compartment 17, Labis Forest Reserve, Segamat, Johor. A total of 24 and 32 saplings in the vicinity of selected mother trees of S. leprosula and D. cornutus, respectively was collected for parentage analysis. Based on SSR polymorphisms, four mother trees of S. leprosula (i.e. SM1, SM9, SM15 and SM21) and three mother trees of D. cornutus (i.e. DM2 or DM3, DM5 and DM8), are not closely related and therefore could be used as potential seed sources for an advanced breeding program. The mean genetic identity of the $S$. leprosula and D. cornutus mother trees was low ( 0.471 and 0.557 , respectively). Low spatial genetic structure within the population of mother trees was detected in S. leprosula and D. cornutus. This implies that extensive gene flow occurred in these species within the seed production areas. This is validated in the present study for D. cornutus where only about $13.3 \%$ of alleles detected in saplings seemed to have originated from adult trees outside the forest seed production area (SPA).
\end{abstract}

Key words: Genetic relatedness, Shorea leprosula, Dipterocarpus cornutus, SSRs, forest seed production areas

\section{INTRODUCTION}

Understanding the genetic structure of forest tree species is a prerequisite for the appropriate utilisation of forest genetic resources, either for genetic improvement for plantation establishment or for management or conservation of natural communities. Although the population structure evolution results from complex interactions of selection, drift and gene flow, tree species with high rates of gene flow should have relatively more genetic variation distributed within and less among populations than species with more limited gene movement (Hamrick \& Nason, 2000). Theoretical studies suggest that restricted gene flow reduces effective population size and causes inbreeding depression (Slatkin, 1985). Therefore, restricted gene flow can become a threat to the viability of populations of outcrossing plants.

Shorea leprosula Miq., commonly known as meranti tembaga, belongs to Dipterocarpaceae, the main timber family in the forests of Southeast Asia. In Peninsular Malaysia, S. leprosula is one of the most common emergent species in lowland dipterocarp forests, lower hill slopes and valleys in hill dipterocarp forests (Symington, 1943). Flowering in S. leprosula, like other dipterocarp species in Mutica section, is sporadic throughout the year and gregarious at intervals of $2-4$ years (Soerianegara \& Lemmens, 1993). Shorea flowers are hermaphroditic, pollinated by insects such as thrips and small beetles (Chan \& Appanah, 1980; Chan, 1980) and produce single seeded fruits; more than half of the mature seeds land within $20 \mathrm{~m}$ of the parent tree (Burgess, 1969). However, if the mother trees are located on hill slopes or ridges, occasionally wind gust can carry the fruit $800 \mathrm{~m}$ away (Kochummen \& Ng 1977).

Dipterocarpus cornutus Dyer, locally known as keruing gombang, belongs to Dipterocarpaceae. This species is widely distributed from Kedah to Singapore, usually on low-lying, flat or undulating land (Symington, 1943). Besides being an important source of heavy hardwood timber, this species is also one of the main oil producing (oleoresin of Dipterocarpus) species in Peninsular Malaysia.

Simple sequence repeats (SSRs) or microsatellite DNA markers are tandemly repeated DNA sequences with core motif

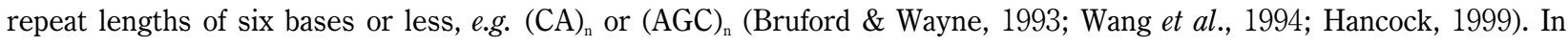
forestry, SSRs have been applied to the study of genetic variation, gene flow, paternity analysis and mating systems because the markers detect high levels of genetic polymorphism (Chase et al., 1996; Dow \& Ashley, 1996; Lefort et al., 1998; Konuma et al., 2000; Obayashi et al., 2002). For instance, Lefort et al., (1998) used nine SSR loci to determine the genetic relatedness 
among elite oak (Quercus robus L.) trees and found that five selected trees were not closely related and could therefore be suitable seed source for an advanced breeding program.

In this study, we determined the genetic relatedness of selected mother trees of S. leprosula and D. cornutus in two SPAs in Compartment 17, Labis Forest Reserve using SSR analysis. We also estimated the magnitude of parentage genotype contribution in S. leprosula and D. cornutus in the SPAs.

\section{MATERIALS AND METHODS}

\section{Field site}

Two seed production areas (SPAs), a 1 hectare seed stand of $S$. leprosula (Figure 1A) and a 0.9 hectare seed stand of $D$. cornutus (Figure 1B) established in Compartment 17, Labis Forest Reserve, Segamat, Johor, Malaysia were used as the study sites.

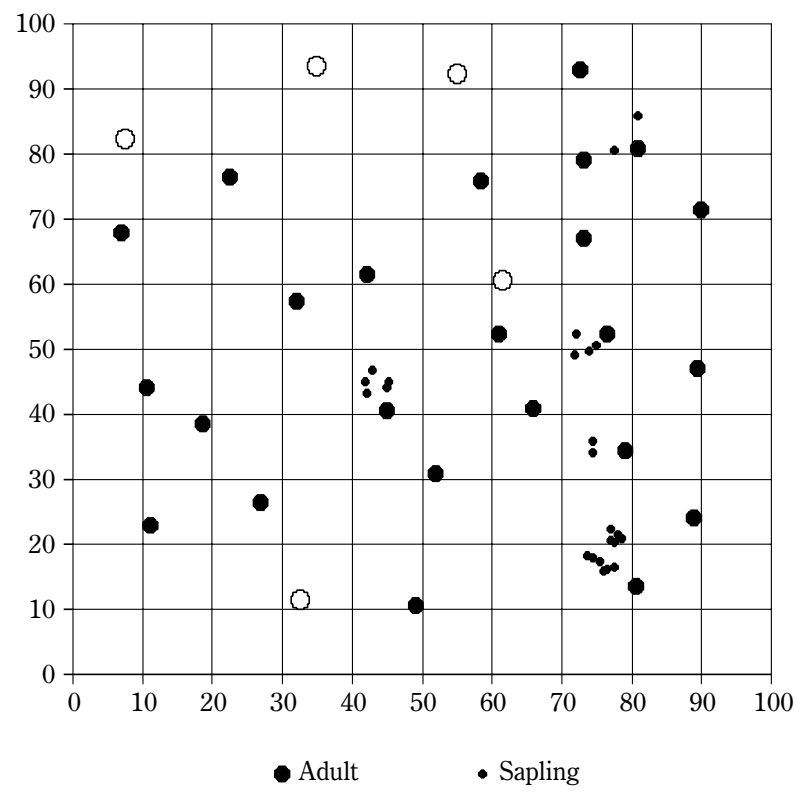

Fig. 1A. Spatial distribution of adult trees $(O)$ and saplings $(\bullet)$ of $S$. leprosula in a 1 hectare seed production area of $S$. leprosula in Compartment 17, Labis Forest Reserve. The unfilled circles $(\bigcirc)$ indicate adult trees that were not selected in this study.

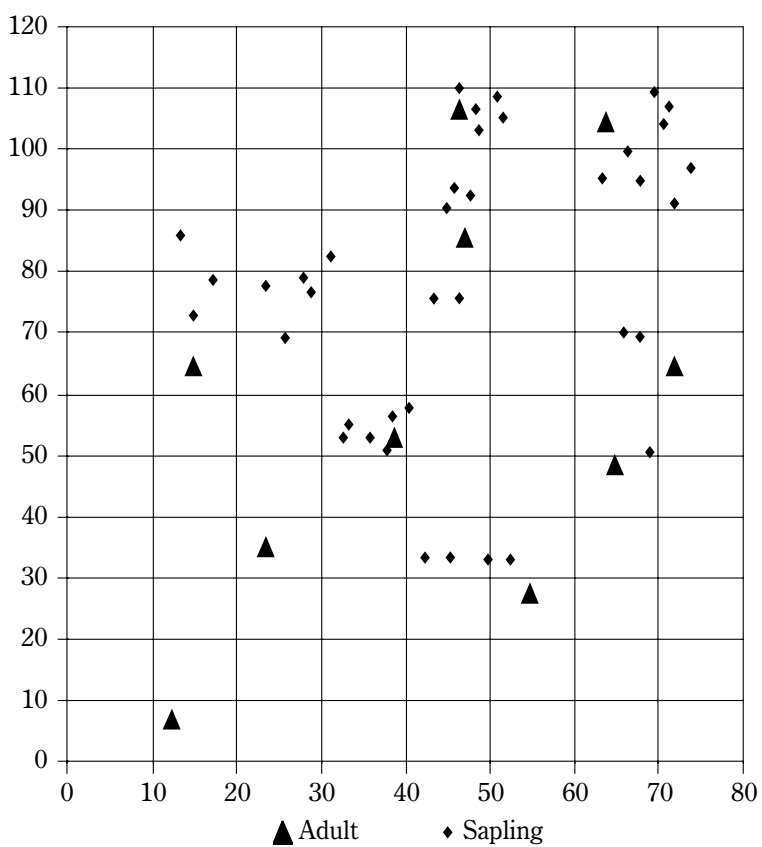

Fig. 1B. Spatial distribution of adult trees $(\Delta)$ and saplings $(\checkmark)$ of $D$. cornutus in a 0.9 hectare seed production area of $D$. cornutus in Compartment 17, Labis Forest Reserve.

\section{Sampling}

Inner bark was collected from all the mother trees in both SPAs, totaling 24 trees of S. leprosula and 10 trees of $D$. cornutus. During sample collection, the spatial distribution of each tree was mapped. In addition, 24 and 32 saplings inside the seed stand were collected in the SPAs of S. leprosula and D. cornutus, respectively. The saplings were assumed to be offsprings of the nearest reproductive trees inside the respective SPA in the forest reserve.

\section{DNA extraction and SSR genotyping}

Total genomic DNA was isolated from the inner bark of mother trees and fresh leaves of saplings, using a modified CTAB method (Murray \& Thompson, 1980; Doyle \& Doyle, 1990). The genotype of each sample was determined using four pairs of SSR primers that were developed in S. curtisii (Ujino et al., 1998). We tested six primer pairs and chose the four that yielded good and consistent amplification products. The details of the SSR loci used for S. leprosula and D. cornutus are listed in Table 1. 
Determination of genetic relatedness of selected individual trees of Shorea leprosula Miq. and Dipterocarpus cornutus Dyer in forest seed production areas

Table 1. Selected SSR loci for $S$. leprosula and $D$. cornutus, core sequence, allele number and optimum primer annealing temperatures used in this study.

\begin{tabular}{|c|c|c|c|c|}
\hline \multirow[b]{2}{*}{ Locus } & \multirow[b]{2}{*}{ Core sequence* } & \multicolumn{2}{|c|}{ Number of alleles observed } & \multirow{2}{*}{$\begin{array}{l}\text { Annealing } \\
\left.\text { Temp. ( }{ }^{\circ} \mathrm{C}\right)\end{array}$} \\
\hline & & Saplings & Adults & \\
\hline \multicolumn{5}{|c|}{ S. leprosula } \\
\hline Shc02 & $(\mathrm{CT})_{2} \mathrm{CA}(\mathrm{CT})_{\mathrm{n}} \mathrm{GC}(\mathrm{AT})_{2}$ & 3 & 3 & 55.2 \\
\hline Shc03 & $(\mathrm{CT})_{\mathrm{n}}$ & 3 & 5 & 56.8 \\
\hline Shc09 & $(\mathrm{CT})_{\mathrm{n}}$ & 7 & 7 & 51.6 \\
\hline \multirow[t]{3}{*}{ Shc11 } & $(\mathrm{CT})_{\mathrm{m}}(\mathrm{A} / \mathrm{T}) \mathrm{T}(\mathrm{CT})_{\mathrm{n}}$ & 4 & 5 & 52.5 \\
\hline & Total & 17 & 20 & \\
\hline & Average & 4.25 & 5.0 & \\
\hline \multicolumn{5}{|c|}{ D. cornutus } \\
\hline Shc02 & $(\mathrm{CT})_{2} \mathrm{CA}(\mathrm{CT})_{\mathrm{n}} \mathrm{GC}(\mathrm{AT})_{2}$ & 3 & 2 & 55.2 \\
\hline Shc03 & $(\mathrm{CT})_{\mathrm{n}}$ & 3 & 3 & 56.8 \\
\hline Shc08 & $(\mathrm{CT})_{\mathrm{n}}$ & 5 & 4 & 52.5 \\
\hline \multirow[t]{3}{*}{ Shc11 } & $(\mathrm{CT})_{\mathrm{m}}(\mathrm{A} / \mathrm{T}) \mathrm{T}(\mathrm{CT})_{\mathrm{n}}$ & 2 & 2 & 52.5 \\
\hline & Total & 13 & 11 & \\
\hline & Average & 3.25 & 2.75 & \\
\hline
\end{tabular}

* $\mathrm{n}$ and $\mathrm{m}$ show the repeated nucleotides (Ujino et al. 1998)

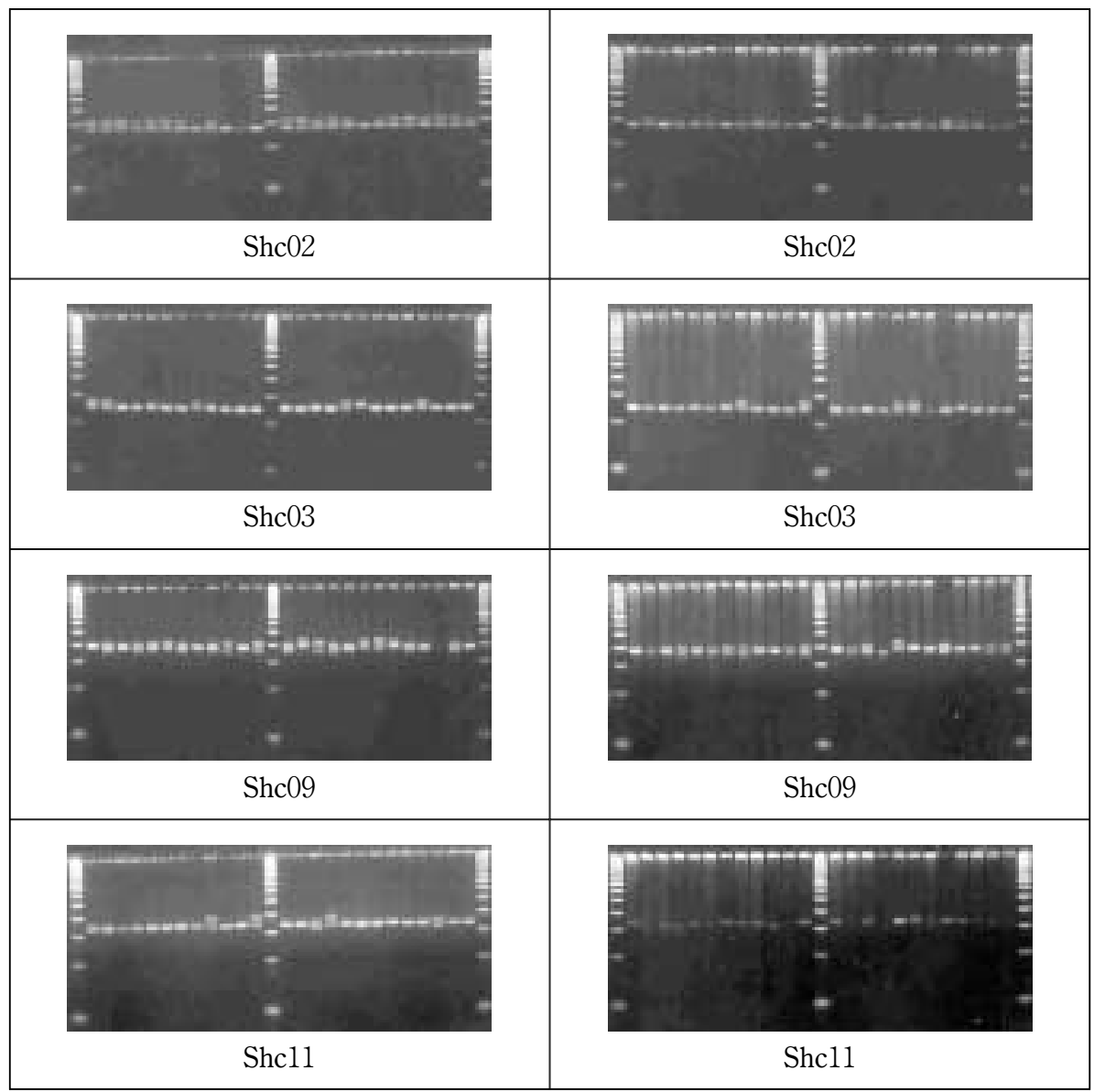

Fig. 2A. SSR polymorphisms in some $S$. leprosula samples from adults (a) and saplings (b) generated by four SSR loci. A 50 bp DNA ladder was used as a DNA size marker. 


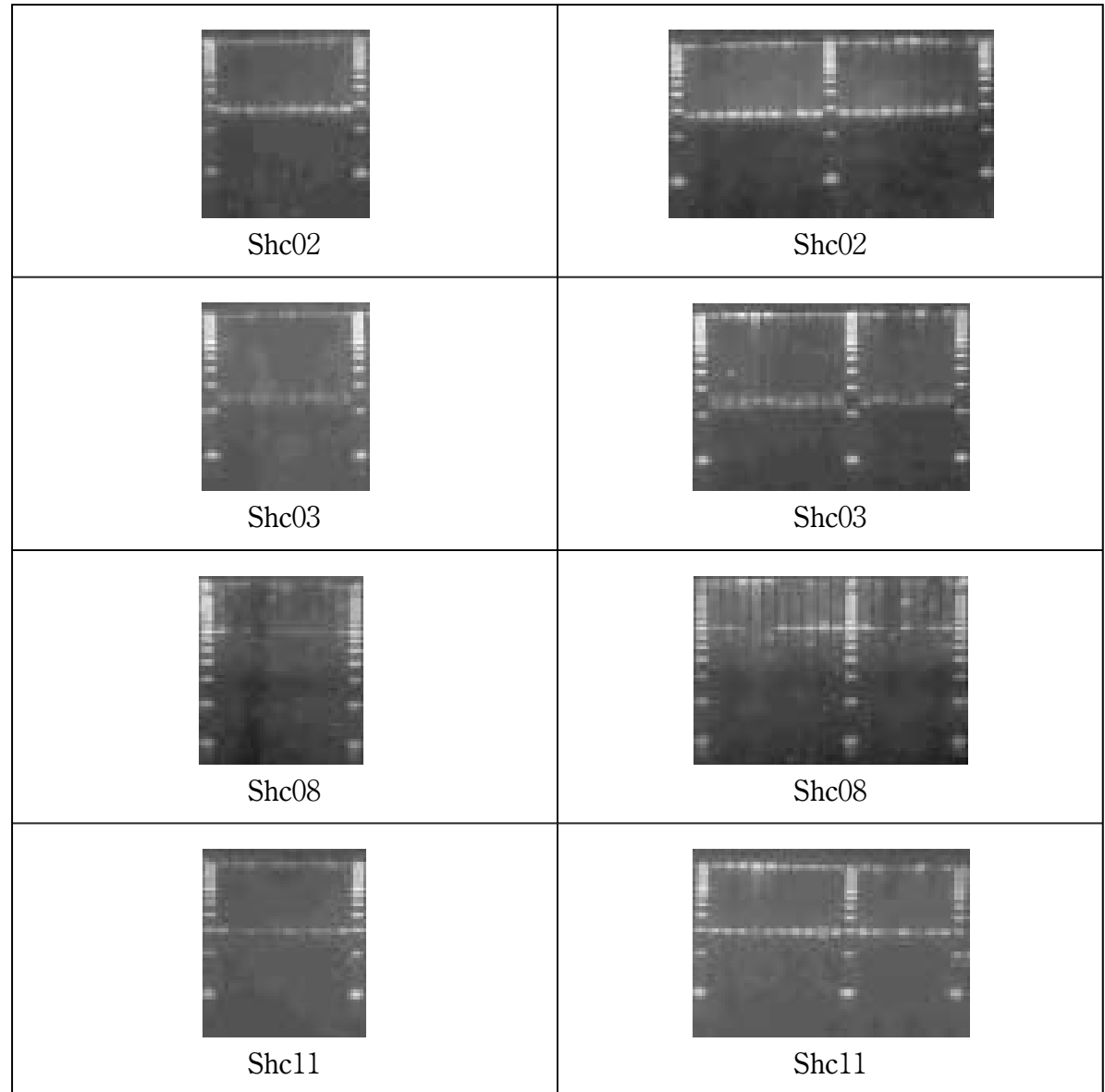

Fig. 2B. SSR polymorphisms in some D. cornutus samples from adults (a) and saplings (b) generated by four SSR loci. A 50 bp DNA ladder was used as a DNA size marker.

Reactions were stopped with $5 \mu 1$ loading dye (15\% Ficoll, 0.25\% Bromophenol blue, and 0.25\% Xylene cyanol FF). 10 $\mu 1$ of the PCR product was separated using 3.5\% Metaphor $^{\mathrm{TM}}$ (FMC Bioproducts, Rockland, Maine) agarose gel in 1x TBE buffer. It should be noted that the $3 \%$ Metaphor $^{\mathrm{TM}}$ agarose gels run in $1 \mathrm{x}$ TBE buffer have a degree of resolution equal to that of a $6 \%$ polyacrylamide gel for the targeted PCR product size range (FMC Bioproducts manual). The gels were run at approximately $80 \mathrm{~V}$ for 3 to 4 hours. After staining with Gelstar ${ }^{\circledast}$ nucleic acid gel stain (FMC Bioproducts, Rockland, Maine) for one hour, the gel was visualised under ultraviolet light. Polaroid 667 film was used to document the gels (Figure 2A and 2B).

\section{Statistical analysis}

The genetic relatedness among all the 24 S. leprosula mother trees and, 10 D. cornutus mother trees was calculated using the Biosys-1 software (Swofford \& Selander, 1981). The probability, $P$ that two different mother trees exhibit identical genotype profiles was also estimated as the mean genetic identity raised to the power of the mean number of alleles per mother tree. In general, relatedness is the probability of sharing an identical-by-descent gene between two individuals (Konuma et al., 2000). Cluster analysis using the genetic identity values via the unweighted pairwise groups with arithmetic averaging (UPGMA, Sneath \& Sokol, 1973) was conducted using an NTSYS-pc computer program (Rohlf, 1990). The spatial distance was also calculated between all mother trees for both species. The correlation between genetic relatedness and spatial distances among these trees was performed using the Mantel test (Mantel, 1967) in an NTSYS-pc computer program (Rohlf, 1990) with 5000 times randomization.

Paternity assignment was conducted by simple exclusion based on multilocus genotypes for the 24 and 10 mother trees 
of S. leprosula and D. cornutus, respectively, using CERVUS 2.0 software (Marshall et al., 1998). Parentage analysis was also conducted by comparing alleles detected between saplings and adults using genotype data at four SSR loci. Alleles at every loci for each sapling were compared with those of adult trees, and adults which did not share any alleles at each locus were excluded as candidate parents.

\section{RESULTS AND DISCUSSION}

\section{Genetic diversity}

All the four SSR loci surveyed were polymorphic in saplings and adults of S. leprosula assayed (Table 2). The number of alleles per locus ranged from three to seven (Table 1) and the average was 4.25 for saplings and 5.0 for adults. The mean expected heterozygosity $\left(\mathrm{H}_{\mathrm{e}}\right)$ detected in saplings and adults for $S$. leprosula was 0.532 and 0.640 , respectively. These values are much higher than previously reported for the same species using allozyme markers; the mean expected heterozygosity was 0.369 (Lee et al., 2001).

Table 2. Estimates of genetic diversity parameters for S. leprosula and D. cornutus in Compartment 17, Labis Forest Reserve. Figures in parentheses are the standard errors.

\begin{tabular}{|c|c|c|c|c|c|c|c|}
\hline & $\mathrm{N}$ & $\mathrm{n}_{\mathrm{a}}$ & $\mathrm{P}(\%)$ & $\mathrm{H}_{o}$ & $\mathrm{H}_{\mathrm{e}}$ & $\mathrm{r}_{\mathrm{b}}$ & Q \\
\hline \multicolumn{8}{|c|}{ S. leprosula } \\
\hline Adults & 24.0 & $\begin{array}{c}5.0 \\
(0.82)\end{array}$ & 100 & $\begin{array}{c}0.490 \\
(0.152)\end{array}$ & $\begin{array}{c}0.640 \\
(0.074)\end{array}$ & 0.091 & 0.891 \\
\hline Saplings & 23.8 & $\begin{array}{c}4.25 \\
(0.95)\end{array}$ & 100 & $\begin{array}{c}0.273 \\
(0.059)\end{array}$ & $\begin{array}{c}0.532 \\
(0.107)\end{array}$ & 0.169 & -- \\
\hline \multicolumn{8}{|c|}{ D. cornutus } \\
\hline Adults & 10.0 & $\begin{array}{c}2.8 \\
(0.5)\end{array}$ & 100 & $\begin{array}{c}0.125 \\
(0.075)\end{array}$ & $\begin{array}{c}0.464 \\
(0.102)\end{array}$ & 0.232 & 0.637 \\
\hline Saplings & 32.0 & $\begin{array}{c}3.25 \\
(0.63)\end{array}$ & 100 & $\begin{array}{c}0.313 \\
(0.171)\end{array}$ & $\begin{array}{c}0.499 \\
(0.133)\end{array}$ & 0.124 & -- \\
\hline
\end{tabular}

Note:

$\mathrm{N}=$ mean sample size per locus; $\mathrm{n}_{\mathrm{a}}=$ mean number of alleles per locus;

$\mathrm{P}=$ percentage of polymorphic loci; $\mathrm{H}_{0}=$ mean observed heterozygosity per locus;

$\mathrm{H}_{\mathrm{e}}=$ mean expected heterozygosity per locus (Nei's 1978);

$\mathrm{r}_{\mathrm{b}}=$ frequency of null alleles, $\left(\mathrm{H}_{\mathrm{e}}-\mathrm{H}_{\mathrm{o}} / 1+\mathrm{H}_{\mathrm{e}}\right.$, Brookfield 1996);

$\mathrm{Q}=$ paternity exclusion probability

In D. cornutus, the number of alleles per locus ranged from two to five and the average was 3.25 for saplings and 2.75 for adults based on four polymorphic SSR loci (Table 2). Meanwhile, the mean expected heterozygosity $\left(\mathrm{H}_{\mathrm{e}}\right)$ detected in saplings and adults of $D$. cornutus was 0.532 and 0.640 , respectively.

\section{Genetic relatedness}

Genetic identities between the S. leprosula mother trees varied between 0.077 (SM13 and SM24) and 1.000 (SM4 and SM7, and SM6 and SM14) (Table 3). The mean genetic identity of the S. leprosula mother trees was 0.471 (N = 276 pairwise comparisons). Thus, the probability of two mother trees being identical by chance is $P=5.8 \times 10^{-2}$.

The dendrogram for $S$. leprosula revealed four main clusters, i.e. Cluster I: SM1; Cluster II: SM2, SM3, SM4, SM5, SM6, SM7, SM8, SM11, SM13, SM14, SM20 and SM23; Cluster III: SM10, SM12, SM17, SM21, SM22, SM24, SM25, SM27 and SM1S, and Cluster IV: SM9 and SM15 (Figure 3). Individual SM21 was distinctly different from the other individuals within cluster III. Based on Figure 3, four mother trees, SM1, SM9, SM15 and SM21, are not closely related and could be used as seed sources.

In D. cornutus, genetic identities among pairs of mother trees varied between 0.000 (DM5 and DM9) and 1.000 (DM2 and DM3) (Table 4). The mean genetic identity between mother trees within the D. cornutus SPA was $0.557(\mathrm{~N}=45$ pairwise comparisons), whereas the probability of two mother trees being identical by chance was $P=1.7 \times 10^{-1}$. However, 
larger $P$ values have been reported when the plants involved were closely related, e.g. $P$ was about $10^{-2}$ for Acer negundo (Nybom \& Rogstad, 1990) and $10^{-3}$ among closely related blackberry cultivars (Nybom et al., 1989). Nevertheless, in some plant species, the chance of fingerprint identity can be relatively low, for instance distance rice cultivars give an identity probability of $10^{-11}$ (Dallas, 1988).

The UPGMA based on Nei's (1978) genetic identity among 10 mother trees of $D$. cornutus are presented in Figure 4. Three distinct clusters were formed; Cluster I: SM1, SM6, SM8 and SM10; Cluster II: SM4, SM5 and SM7, and Cluster III: SM2, SM3 and SM9. Within cluster I individual SM8 was different from the other individuals, whereas in cluster II individual M5 was distinctly different from individuals M4 and M7. The cluster analysis showed that cluster I was more closely related to cluster II than to cluster III. Based on Figure 4, the individuals SM2 or SM3, SM5, SM8 and SM9 are not closely related and can be used for seed production.

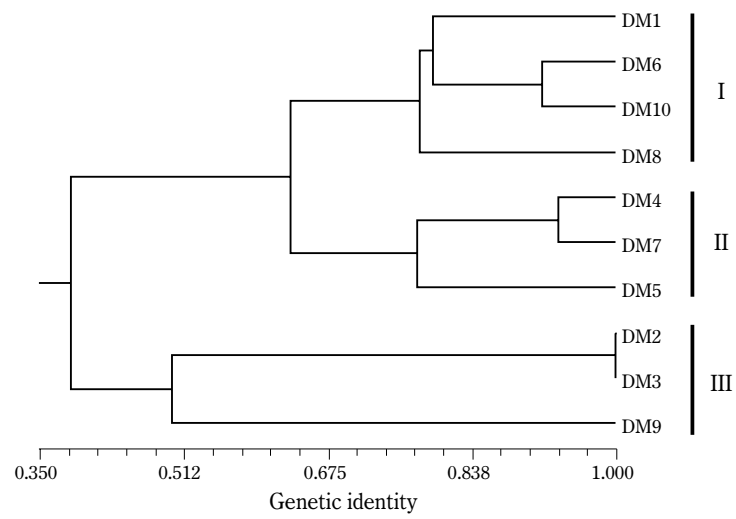

Fig. 4. UPGMA cluster analysis based on Nei's (1978) genetic identity among 10 mother trees of $D$. cornutus in a 0.9 hectare SPA of $D$. cornutus in Compartment 17, Labis Forest Reserve, Segamat, Johor.

Table 3. Genetic identity between pairs of mother trees of $S$. leprosula

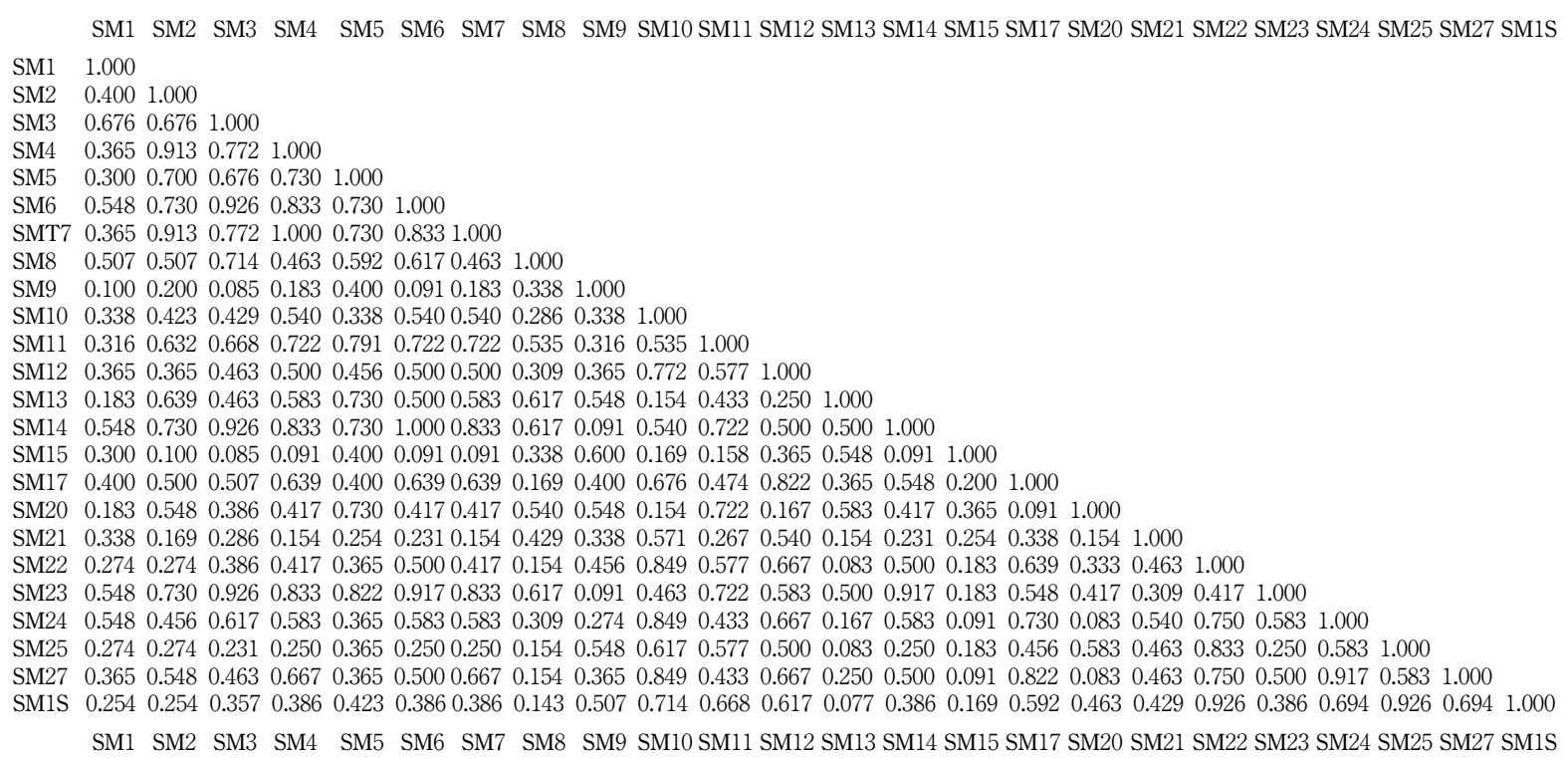

Note: The mean pairwise genetic identity among 24 mother trees of S. leprosula is 0.471 . 


\section{Table 4. Genetic identity between pairs of mother trees of $D$. cornutus}

DM1 DM2 DM3 DM4 DM5 DM6 DM7 DM8 DM9 DM10

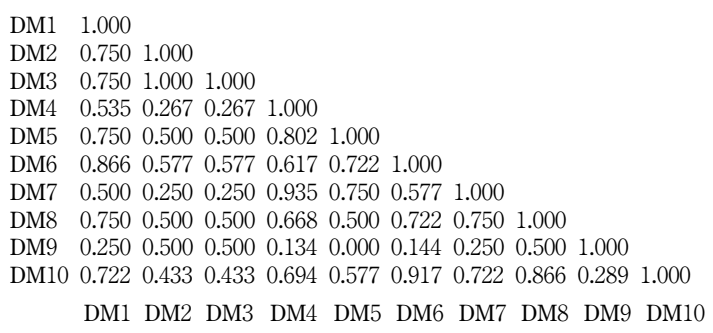

Note: The mean pairwise genetic identity among 10 mother trees of $D$. cornutus is 0.557 .

Lefort et al. (1998) used nine SSR loci to determine the genetic relatedness among elite oaks (Quercus robus L.) trees. They found that five selected trees were not closely related and would therefore form suitable seed sources for an advanced breeding program.

\section{Genetic structure}

Figure 5 shows the plot of all pairwise genetic identity between $S$. leprosula and $D$. cornutus mother trees against the corresponding geographical distance. A negative correlation was detected in the S. leprosula population $(\mathrm{r}=-0.112, \mathrm{P}=$ 0.07, Mantel test, Figure 5A), meanwhile the D. cornutus population showed a negative and significant correlation $(\mathrm{r}=$ $0.467, \mathrm{P}=0.003$, Mantel test, Figure 5B).

(A)

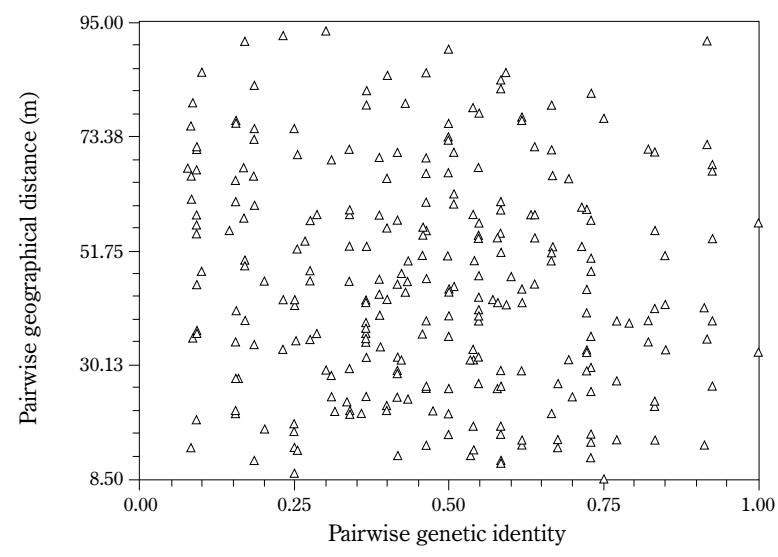

(B)

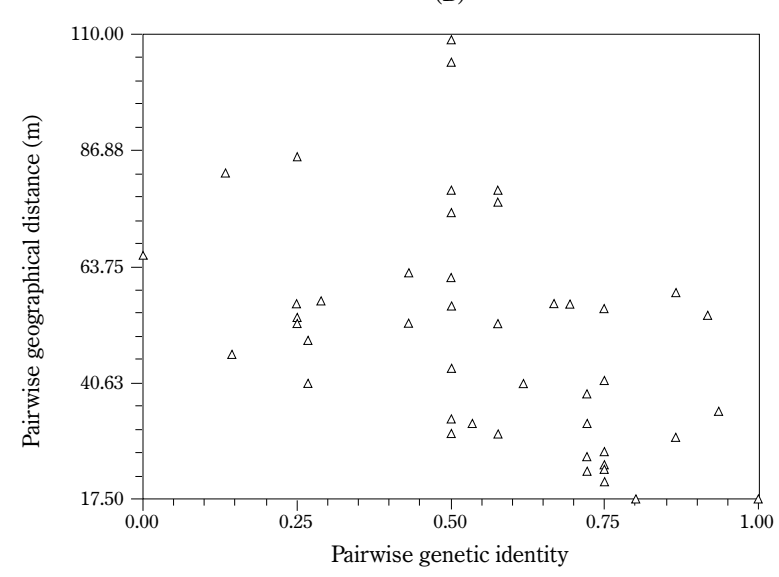

Fig. 5. Relationship between pairwise geographical distance and pairwise genetic identity for the S. leprosula population (A) and the $D$. cornutus population (B).

If there was a genetic structure within these mother trees, there would be a clear negative correlation and a high $r$ value (Mantel test) would be expected between these parameters. Genetic structure, the genetic differentiation within a population, is induced when gene flow by pollen and seed dispersal is limited (Konuma et al., 2000). Therefore, these results indicate that the spatial genetic structure among the 24 and 10 mother trees of $S$. leprosula and D. cornutus, respectively, in the SPA was low. This further implies extensive gene flow in previous generations in the populations. A similar result was also detected in 30 mother trees of Neobalanocarpus heimii in a 42-ha study plot, Pasoh Forest Reserve (Konuma et al., 2000). They suggested that long-distance gene flow and seed migration are responsible for the poorly developed genetic structure in this species.

According to Isagi et al. (2000), if a population is genetically structured and inbreeding or outbreeding depression occurs, as indicated by the genetic relatedness of adult trees, some kind of selection on pollen grains could have occurred. Dow and Ashley (1996) presumed the existence of a mechanism allowing female flowers of Quercus macrocarpa to 
preferentially select pollen from distant sources rather than pollen produced by neighbouring trees.

Chase et al. (1996) revealed that most mating events in Pithecellobium elegans were not between the closest neighbours, because of variations in phenology or flowering behaviour among adult trees. Many tree species show large fluctuations in flowering among years with or without synchronisation between trees in a population. In the case of episodic flowering without synchronisation in a population, only some of the trees in a population can contribute to reproduction in a given year and this may have resulted from pollination between distant trees. Isagi et al. (2000) reported that more than $70 \%$ of the pollination events in Magnolia obovata occurred between non-nearest neighbours.

\section{Parentage analysis}

The total exclusion probability, the exclusion probability in the case of both parents being unknown (Marshall et al., 1998), over four SSR loci for S. leprosula and D. cornutus was 0.891 and 0.637 , respectively (Table 2). The paternity exclusion probability detected in $S$. curtisii (K. Obayashi, personal communication) and N. heimii (Konuma et al., 2000) using the same primer systems (Ujino et al., 1998) was 0.97 .

Pemberton et al., (1998) reported that the null alleles are responsible for mismatches between parent-offspring pairs, i.e. the offspring do not amplify an allele that is present in the parents. In addition, the presence of null alleles will bias the estimation of genotype and allele frequencies (Dowling et al., 1997). In this study, the frequency of null alleles detected in adult trees of S. leprosula and D. cornutus were $9.1 \%$ and $23.2 \%$, respectively (Table 2). Callen et al. (1993) found that in a survey of (AC) $)_{n}$ SSR markers in human, 7 or $30 \%$ of the 23 markers surveyed demonstrated the presence of null alleles. In addition, Roa et al. (2000) in their study on cross-species amplification of Manihot species using 10 SSR loci found the presence of null alleles in Manihot species was on average about $11 \%$. Null allele detected in locus Shc02 for N. heimii was probably caused by mismatches between parent and offspring (Konuma et al., 2000).

Based on the parentage analysis, about $13.3 \%$ of the alleles detected in D. cornutus saplings (Table 5A and 5B) probably originated from adult trees outside the SPA. This implies gene flow occurred in this species within the SPA. Isagi et al. (2000) found that about 57\% of the possible parents of Magnolia obovata saplings were from outside the study plot in Ogawa Forest Reserve revealed by eight SSR loci.

Table 5A. Parentage analysis for D. cornutus in SPA, Compartment 17, Labis Forest Reserve.

\begin{tabular}{lll}
\hline & \multicolumn{2}{c}{ Observed alleles } \\
\cline { 2 - 3 } Locus & \multicolumn{1}{c}{ Adults } & \multicolumn{1}{c}{ Saplings* } \\
\hline Shc02 & A, B & $\underline{\mathrm{B}}, \mathrm{C}$ \\
Shc03 & A, B, C & $\underline{\mathrm{A}}, \underline{\mathrm{B}}, \underline{\mathrm{C}}$ \\
Shc08 & A, C, D, E & $\underline{\mathrm{A}}, B, \underline{\mathrm{C}}, \underline{\mathrm{D}}, \underline{\mathrm{E}}$, \\
Shc11 & A, B & $\underline{\mathrm{A}}, \underline{\mathrm{B}}$ \\
\hline
\end{tabular}

Note:

Underlined alleles probably originated from adult trees within the seed production area (SPA).

Italicised alleles probably originated from adult trees outside the seed production area (SPA).

Table 5B. Parentage allele contribution in $D$. cornutus in SPA, Compartment 17, Labis Forest Reserve.

\begin{tabular}{ccc}
\hline \multirow{2}{*}{ Locus } & \multicolumn{2}{c}{ Parentage allele contribution $(\%)$} \\
\cline { 2 - 3 } & \multicolumn{2}{c}{ Saplings } \\
\cline { 2 - 3 } Shc02 & Within SPA & Outside SPA \\
Shc03 & 66.7 & 33.3 \\
Shc08 & 100.0 & 0.0 \\
Shc11 & 80.0 & 20.0 \\
Mean & 100.0 & 0.0 \\
\hline
\end{tabular}

\section{Note:}

Within SPA means alleles probably originated from adult trees within the SPA. Outside SPA means alleles probably originated from adult trees outside the SPA.

In contrast, all the saplings of S. leprosula shared the same alleles with mother trees inside the S. leprosula SPA at each locus (Table $6 \mathrm{~A} \& 6 \mathrm{~B}$ ). This result suggests that these mother trees are probably their parents. Nevertheless, there are possibilities that these alleles detected in saplings may also come from S. leprosula mother trees outside the S. leprosula SPA 
in Compartment 17. According to Isagi et al. (2000), more than $70 \%$ of the pollination events in $M$. obovata occurred between non-nearest neighbours. In fact, the average mating distance, $524 \mathrm{~m}$, has been reported in $N$. heimii based on five reproductive trees in Pasoh Forest Reserve, a lowland tropical rainforest in Malaysia (Konuma et al. 2000).

Table 6A. Parentage analysis for S. leprosula in SPA, Compartment 17, Labis Forest Reserve.

\begin{tabular}{lll}
\hline & \multicolumn{2}{c}{ Observed alleles } \\
\cline { 2 - 3 } Locus & \multicolumn{1}{c}{ Adult } & \multicolumn{1}{c}{ Sapling* } \\
\hline Shc02 & A, B, C & $\underline{\mathrm{A}}, \underline{\mathrm{B}}, \underline{\mathrm{C}}$ \\
Shc03 & A, B, D & $\underline{\mathrm{A}}, \underline{\mathrm{B}}, \underline{\mathrm{D}}$ \\
Shc09 & A, B, C, D, E, F, G & $\underline{\mathrm{A}}, \underline{\mathrm{B}}, \underline{\mathrm{C}}, \underline{\mathrm{D}}, \underline{\mathrm{E}}, \underline{\mathrm{F}}, \underline{\mathrm{G}}$ \\
Shc11 & A, B, C, D, E & $\underline{\mathrm{A}}, \underline{\mathrm{B}}, \underline{\mathrm{C}}, \underline{\mathrm{D}}$ \\
\hline
\end{tabular}

Note:

Underlined alleles probably originated from adult trees within the seed production area (SPA).

Table 6B. Parentage allele contribution in S. leprosula in SPA, Compartment 17, Labis Forest Reserve.

\begin{tabular}{ccc}
\hline \multirow{2}{*}{ Locus } & \multicolumn{2}{c}{ Parentage allele contribution (\%) } \\
\cline { 2 - 3 } & Sapling \\
\cline { 2 - 3 } Shc02 & Within SPA & Outside SPA \\
Shc03 & 100.0 & 0.0 \\
Shc09 & 100.0 & 0.0 \\
Shc11 & 100.0 & 0.0 \\
Mean & 100.0 & 0.0 \\
\hline
\end{tabular}

Note:

Within SPA means alleles probably originated from adult trees within the seed production area (SPA).

Outside SPA means alleles probably originated from adult trees outside the seed production area (SPA).

\section{CONCLUSION}

The application of SSRs in the present study successfully distinguished four mother trees of S. leprosula (SM1, SM9, SM15 and SM21) and D. cornutus (DM2 or DM3, DM5 and DM8), from two SPAs in Compartment 17, Labis Forest Reserve, Segamat, Johor, respectively. These mother trees are not closely related and therefore form potential seed sources for an advanced breeding program. Low spatial genetic structure within the populations of mother trees was detected in $S$. leprosula and D. cornutus seed stands. This implies that gene flow occurred in these species within the SPA. This is validated in the present study for D. cornutus where about $13.3 \%$ of the sapling alleles detected seem to have originated from adult trees outside the SPA.

ACKNOWLEDGMENTS The authors would like to thank Mr. Sheikh Ibrahim Sheikh Ali and his staff at Labis F.R. Station for the SPA tree map data and the Forest Department of Peninsular Malaysia for providing the funds for this study.

\section{REFERENCES}

Brookfield, J.F.Y. 1996. A simple new method for estimating null allele frequency from heterozygote deficiency. Molecular Ecology 5: 453-455.

Bruford, M. \& Wayne, R. 1993. Microsatellites and their application to population genetic studies. Current Opinion in Genetics and Development 3: 939-943.

Burgess, P.F. 1969. Preliminary observations on the autecology of Shorea curtisii Dyer ex King in the Malay Peninsula. Malaysian Forester 32: 438.

Callen, D.F., Thompson, A.D., Shen, Y., Phillips, H., Richards, R.I., Mulley, J.C. \& Sutherland, G.R. 1993. Incidence and origin of null alleles in the (AC) $)_{n}$ microsatellite markers. American Journal of Human Genetics 52: 922-927.

Chan, H.T. \& Appanah, S. 1980. Reproductive biology of some Malaysian dipterocarp. I. Flowering biology. Malaysian 
Forester 43: 132-143.

Chan, H.T. 1980. Reproductive biology of some Malaysian dipterocarp. II. Fruiting biology and seedling studies. Malaysian Forester 43: 438-451.

Chase, M.R., Moller, C., Kesseli, R. \& Bawa, K.S. 1996. Distant gene flow in tropical trees. Nature 383: 398-399.

Dallas, J.F. 1988. Detection of DNA fingerprints of cultivated rice by hybridization with a human minisatellite DNA probe. Proc. Natl. Acad. Sci. USA 85: 6831-6835.

Dow, B.D. \& Ashley, M.V. 1996. Microsatellite analysis of seed dispersal and parentage of saplings in bur oak, Quercus macrocarpa. Molecular Ecology 5: 615-627.

Dowling, T.E., Moritz, C., Palmer, J.D. \& Rieseberg, L.H. 1997. Nucleic Acids III: Analysis of fragments and restriction sites. In Molecular Systematics 2nd (D.M. Hillis eds), 249-320. Sinauer Assocs. Inc., Massachusetts.

Doyle, J. \& Doyle, L. 1990. Isolation of plant DNA from fresh tissue. Focus 12: 13-15.

Hamrick, J.L. \& Nason, J.D. 2000. Gene flow in forest trees. In Forest Conservation Genetics: Principles and Practice (A.Young eds), 81-90. CSIRO Publishing, Australia.

Hancock, J.M. 1999. Microsatellites and other simple sequences: genomic context and mutational mechanisms. In Microsatellites: Evolution and Applications (D.B. Goldstein \& C. Schlötterer eds), 1-9. Oxford University Press, Oxford.

Isagi, Y., Kanazashi, T., Suzuki, W., Tanaka, H \& Abe, T. 2000. Microsatellite analysis of the regeneration process of Magnolia obovata Thunb. Heredity 84: 143-151.

Kochummen, K.M. \& Ng, F.S.P. 1977. Natural plant succession after farming in Kepong. Malayan Forester 40: 61-78.

Konuma,A., Tsumura, Y., Lee, C.T., Lee, S.L. \& Okuda, T. 2000. Estimation of gene flow in the tropical-rainforest tree Neobalanocarpus heimii (Dipterocarpaceae), inferred from paternity analysis. Molecular Ecology 9: 1843-1852.

Lee, S.L., Wickneswari, R., Mahani, M.C. \& Zakri, A.H. 2001. Genetic diversity of a tropical tree species, Shorea leprosula Miq. (Dipterocarpaceae), in Malaysia: Implications for conservation of genetic resources and tree improvement. Biotropica 32: 213-224.

Lefort, F., Lally, M., Thompson, D. \& Douglas, G.C. 1998. Morphological traits, microsatellite fingerprinting and genetic relatedness of a stand of elite oaks, Quercus robur L. at Tullynally, Ireland. Silvar Genetica 47: 257-262.

Mantel, N. 1967. The detection of disease clustering and a generalized regression approach. Cancer Research 27: 209-220.

Marshall. T.C., Slate, J., Kruuk, L.E.B., Pemberton, J.M. 1998. Statistical confidence for likelihood-based paternity inference in natural populations. Molecular Ecology 7: 639-655.

Murray, M.G. \& Thompson, W.F. 1980. Rapid isolation of high molecular weight plant DNA. Nucleic Acids Research 8: 43214325.

Nybom, H. \& Rogstad, S.H. 1990. DNA fingerprints detect genetic variation in Acer negundo (Aceraceae). Plant Systematic Evolution 173: 49-56.

Nybom, H., Schaal, B.A. \& Rogstad, S.H. 1989. DNA fingerprints can distinguish cultivars of blackberries and raspberries. Acta Hortic. 262: 310-315.

Obayashi, K., Tsumura, Y., Ihara-Ujino, T., Niiyama, K., Tanouchi, H., Suyama, Y., Washitani, I., Lee, C.T., Lee, S.L. \& Norwati, M. 2002. Genetic diversity and outcrossing rate between undisturbed and selectively logged forests of Shorea curtisii (Dipterocarpaceae) using microsatellite DNA analysis. Int. J. Plant Sci. 163: 151-158.

Pemberton, J.M., Slate, J., Bancroft, D.R. \& Barrett, J.A. 1995. Nonamplifying alleles at microsatellite loci: a caution for parentage and population studies. Molecular Ecology 4: 249-252.

Roa, A.C, Chavarriaga-Aguirre, P., Duque, C.M., Maya, M.M., Bonierbale, M.W., Iglesias, C. \& Tohme, J. 2000. Crossspecies amplification of cassava (Manihot esculenta) (Euphorbiaceae) microsatellites: allelic polymorphism and degree of relationship. American Journal of Botany 87(11): 1647-1655.

Rohlf, F.J. 1990. NTSYS-pc, Numerical Taxonomy and Multivariate Analysis System. Version 1.60. Applied Biostattistic Inc., New York.

Slatkin, M. 1985. Gene flow in natural populations. Annual Review of Ecology and Systematics 16: 393-430.

Sneath, P.H.A. \& Sokal, R.R. 1073. Numerical Taxonomy. San Francisco: W.H. Freeman Press.

Soerianegara, I \& Lemmens, R.H.M.J. 1993. Plant Resources of South-East Asia. No. 5(1). Timber trees: Major Commercial timbers. Pudoc Scientific Publishers, Wageningen.

Swofford, D.L. \& Selander, R.B. 1981. BIOSYS-1: A FORTRAN program for the comprehensive analysis of electrophoretic data in population genetics and systematics. Journal of Heredity 72: 281-283. 
Determination of genetic relatedness of selected individual trees of Shorea leprosula Miq. and Dipterocarpus cormutus Dyer

Symington, C.F. 1943. Foresters' manual of dipterocarps. Malayan Forester Records 16. University of Malaya Press, Kuala Lumpur.

Ujino, T., Kawahara, T., Tsumura, Y., Nagamitsu, T., Yoshimaru, H. \& Wickneswari, W. 1998. Development and polymorphism of simple sequence repeat DNA markers for Shorea curtisii and other Dipterocarpaceae species. Heredity 81: 422-428.

Wang, Z.Y., Weber, J.L., Zhong, G. \& Tanksley, S.D. 1994. Survey of plant short tandem DNA repeats. Theoretical and Applied Genetics 88: 1-6.

Received $4^{\text {th }}$ Oct. 2003

Accepted $1^{\text {th }}$ Dec. 2003 